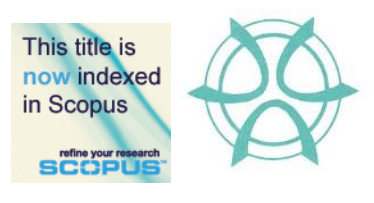

PLANNING MALAYSIA:

Journal of the Malaysian Institute of Planners

VOLUME 16 ISSUE 1 (2018), Page 75 - 87

\title{
THE VIABILITY OF AN INTEGRATIVE FRAMEWORK FOR URBAN DESIGN AND REGIONAL ENVIRONMENTAL JUSTICE
}

\author{
Stephen T.F. Poon ${ }^{1}$ \\ ${ }^{1}$ School of Media, Arts \& Design \\ ASIA PACIFIC UNIVERSITY OF TECHNOLOGY \& INNOVATION MALAYSIA
}

\begin{abstract}
Environmental justice is an increasingly problematic proposition, as the clash of political, economic, social and community interests invariably occur. The purpose of this research is to examine the viability of an integrated framework that establishes environmental justice from economic, social and cultural development perspectives in Malaysia. Case studies analysing Iskandar Low Carbon Blueprint (LCB) 2025 and the River of Life Project (ROL) are presented. Findings suggest that clear national policies on urban transformation is an increasingly important environmental justice issue in Malaysia, but sustaining liveability is a challenge in the face of more critical decisions on infrastructural and resource management and energy use, resulting in a lack of attitudinal and behavioural change in urban planning programmes. This suggests that meaningful stakeholder engagements and collaborations contribute in planning economically and ecologically viable solutions and initiatives for liveable and resilient cities.
\end{abstract}

Keyword: sustainability, liveable, resilient urban design, environmental justice 
Stephen T.F. Poon

The Viability of an Integrative Framework for Urban Design and Regional Environmental Justice

\section{INTRODUCTION}

Urban design is an interdisciplinary field incorporating scientific inquiry and empirical research related to architecture, spatial, aesthetic and cultural landscape planning and development (Dovey \& Pafka, 2016). Within the practice however, contestations occur: political and economic investment priorities, intertwined with issues of resource and energy dependence, and divergent sociocultural and ecological interests, make urban planning the site of critical studies on placemaking, climate change, socio-ecological restoration and environmental justice (Carmona, 2013; Hens \& Stoyanov, 2014).

To understand these issues, cases assessing urban design's role in serving environmental justice are examined in this article. Key research questions include: What is the relationship between environmental justice and sustainable design in the planning of urban communities? How is urban design integrated into planning policies? What is Malaysia's rate of success in fostering environmental justice programmes?

Countries blessed with abundant natural resources consider themselves well-buffered against climate change since vast assets enable them to support large-scale consumption. Examining data on the contributors of carbon emission, however, urban cities are found to be core carbon producers: consuming twothirds of the world's energy and generating $70 \%$ of global emission of harmful pollutants (World Bank, 2014). Compounded by a lack of regulatory awareness and advocacy emphasising environmental justice from top-down and bottom-up channels; a lack of participatory dialogues addressing social injustices towards low- or mixed-income urban dwellers $(\mathrm{C} 40,2016)$ results.

Malaysia must thus increasingly commit to tackling complex global issues such as climate change, urban resilience, and participate in resource efficiency management for several reasons, chief of which is to fully reap the benefit-sharing outcomes of collaborative sustainable strategies and long-range initiatives. With Malaysia now at a critical stage of transformation, the enhancement of socio-spatial surroundings demands a new state of human culture, where the value of environmental wellbeing is cultivated at fundamental and advanced levels among growing populations of urban communities. This article examines the degree in which environmental justice, a concept integrating urban design planning and national urban transformation mechanisms, is actionable in the long term economic development and planning of Malaysian cities.

\section{LITERATURE REVIEW}

Urban design is the application of concepts and practices to seek the elusive, but desirable, condition of comparative better quality of life. It evolved from the discipline of ecological economics, a branch of a larger global movement concerned with addressing change through collective action and civic 
PLANNING MALAYSIA

Journal of the Malaysia Institute of Planners (2018)

participation in debating regulatory measures, utilising technical and technological solutions (Pieterse, 2001). As an integrated field, this practice requires modern approaches to normative intervention strategies, mechanisms, policies and processes that instigate actions and produce change.

Environmental justice is defined broadly as the "fair treatment and meaningful involvement of people regardless of race, colour, national origin, or income with respect to the development, implementation and enforcement of environmental laws, regulations, and policies" (US EPA, 2017). The US EPA aligns environmental policies with urban design planning through guiding frameworks, collaborative decision-making processes and systems implementation in efforts to create climate-resilient and robust surroundings for balanced urban growth.

The overall aim of environmental justice is to provide equity of care for society and the environment through accelerating green policies and promoting best practices and choices in planning and designing urban spaces (Washburn, 2013). Simply put, sustainable development cannot be achieved without environmental justice. Not all are advocates of this approach, however. Sustainability is contested by urbanisation critics and researchers, who challenge the validity of environmentalism to achieve social justice, calling it a "smoke screen" under the traditional economic ideology as ethnic and class disparities persist (Bullard, 2000), while polarities of urban development are ambiguously represented. Countries transitioning from a traditional to global economy face constraints of state budgetary allocations which impact the social landscapes and pace of life that differentiates smaller towns from metropolises (Bettencourt, Lobo, Helbing, Kühnert, \& West, 2007; Walker \& Salt, 2006).

Jacobs' (1999) four "faultlines" theory suggests that growth limitations, environmental objectives, social equity and participation influence the equitable distribution of welfare and access to amenities and facilities. Residential and industrial zoning, for instance, forces the reorganisation of social classes based on income and demographics, green hubs that subdivide public areas proport to perpetuate raw elements such as trees, gardens and walking paths, but may eventually be cordoned off as private recreational zones.

Environmental management must not merely be table talk among those with prevailing knowledge, but intentional dialogues with disenfranchised or resource-poor groups (Martin, McGuire, \& Sullivan, 2013). As urban space planning affect water quality and hydrological services, the processes could impact indigenous flora and fauna. McCluskey and Joao (2011) propose the implementation of environmental justice policies by recognising the importance of species diversity and habitat protection, whereby sustainability actions are informed by consultation with environmental institutions and bodies. Evidence of urban design quality can be evaluated by assessing visual aesthetics' role to enrich social experiences and eco-interactions (Cullen, 1961; Gobster, Nassauer, 
Stephen T.F. Poon

The Viability of an Integrative Framework for Urban Design and Regional Environmental Justice

Daniel, \& Fry, 2007), for instance, the conversion of courtyards, balconies or rooftops into vegetable farms, herbal or flower gardens (IDRC, 2006). By being "just green enough", small-scale methods help address environmental justice better, in lieu of oversized public projects that concentrate resources in affluent neighbourhoods and introduce gentrification, forcing poorer residents to be resettled in less liveable regions as a result (Wolch, Byrne, \& Newell, 2014).

\section{Relationship between Environmental Justice and Urban Design}

Environmental justice can be a catalyst for ideal 'healthy communities' by ensuring balance in social access to housing and employment and sustaining property values (Wolch et al., 2014). Adaptiveness, resilience, wellbeing, sustainability and liveability are found through the interstices of spatial design, in the "intensities, rhythms and socialities" represented by people's synergies, psychosocial and cultural dimensions. US EPA (2017) notes that neighbourhoods with infrastructural connectivity, pedestrian walkability, transit amenities and public conveniences, when combined with spatial aesthetics, appeal to people at all stages of life and income levels. This state of social equity starts from identifying the scale of environmental degradation (Martin et al., 2013). Sustainable urban design addresses another aspect: the moral nature of human resilience itself. Deliberate policies and actions to reduce energy use and resource dependency, slow the rate of climatic changes, improve communal wellbeing and encourage adoption of green technologies, are crucial (Washburn, 2013), yet urban planning are seldom financially rewarding in the short term, and few acknowledge the practice as explicitly just: it is hard to make an economic case for design per se, being subjective and "slippery in nature", since what is considered 'the best' or 'most rational' planning solution for greater good may merely be advantageous for dominant stakeholders (Carmona \& Tiesdell, 2007). Rice and Littlefield (2015) reviewed post-industrial recessionary failure of American real estate and found that sheer commercial misjudgements transgress on architecture, resulting in illegal squatting in derelict properties, abandoned factories, and fringe settlements.

Nassauer and Raskin (2014) argue similarly that vacant properties and abandoned land tracts are vulnerable to contaminants, defined as accumulated negative physical legacies such as building defacement, or wanton dumping of household debris, chemicals and littering, resulting in sociocultural decay and criminal risks. Transformative solutions ranging from land use conversion, intentional landscaping and social capital investments stressing development of communal ties are necessary to demonstrate "cues to care", strengthening perceptions of safety and reducing residential fears (Nassauer \& Raskin, 2014).

In summing up literature, environmental duties are the underpinning principles in urban design planning to assure fair and equitable access of diverse communities to green spaces (Wolch et al., 2014). Planners must also consider 
PLANNING MALAYSIA

Journal of the Malaysia Institute of Planners (2018)

how eco-design changes affect groups living on the fringes of urban areas. Environmental justice can be integrated into sustainability frameworks through social equity agenda. These goals require stakeholder action groups comprising public and private sectors to be involved in planning, decision-making and implementation (Aiyeola, Ramdzani, Nasir, \& Zalina, 2014; Nassauer, Wu, \& Xiang, 2014; World Bank, 2014). Literature suggests that careful analysis of prevailing assumptions, attitudes and perceptions about sustainability is crucial, as community input legitimises sustainability at the core of environmental agendas by questioning "who gets what, why, and how much" (Bullard, 2008).

\section{RESEARCH BACKGROUND AND METHODOLOGY}

The use of qualitative case study, while evidently limited to specific cases, provides contextual analysis and broad interpretation of findings for complex phenomena (Yin, 2003). Observed phenomena combined with inductive methods make case studies instrumental in discovering motivations behind cultural behaviour patterns (Stake, 1995). To deconstruct relations between people, and relations between people to places and objects (e.g. buildings), narrative cases represent a humanities dimension, complementing empirical research. Qualitative studies on urban design challenges uses descriptive insights (Bettencourt et al., 2007; Dovey \& Pafka, 2016), enabling economists, politicians, policymakers and researchers to understand environmental parity in evaluating problems, constraints and solutions beyond financial benefits, since projects may be viewed as "successful in somebody's eyes and [yet be] failures in somebody else's" (Lang, 2005, p. xxiii). Case study method cuts through objective and subjective data to seek how "assemblage of adaptive social interconnections link spatiality to sociality" in urban spaces (Dovey \& Pafka, 2016, p.10).

\section{FINDINGS AND ANALYSIS}

This research offers a unique insight on the impact of Malaysian urban design planning policies on environmental justice by examining how the participatory model of interaction affects outcomes of two urban projects. 
Stephen T.F. Poon

The Viability of an Integrative Framework for Urban Design and Regional Environmental Justice

\section{Case Study I: ISKANDAR Low Carbon Blueprint 2025}

In an ideal sustainable urban ecosystem, urban design principles thrive alongside significant transformative changes. Under Malaysia's Ministry of Energy, Green Technology and Water (KeTTHA, 2009), a Low Carbon Cities framework involving collaboration with non-profit Carbon Trust UK is aimed at accelerating transition towards a low carbon economy. Quantitative factors include measuring carbon footprint per capita, increase in renewable energy, usage of clean technologies and energy-efficiency solutions for cost reductions among participating stakeholders (Rugg, 2014). The Low Carbon Blueprint (LCB 6-11) 2025 for Iskandar City in Johor exemplifies top-down and bottom-up approaches in enhancing urban infrastructural planning via social engineering and sustainability projects involving state authorities, civil agencies, NGO and private sectors (Figure 1). Under the LCB 2025, local planning authorities, civic communities and private sector networks were identified as stakeholders in development planning by policymakers, guided by the Town and Country Planning Act 1976.

Among the many thrusts, LCB 2025 targets for land use and infrastructural transformation through transit-oriented development or TODs (LCB 9-15). By building transport interchanges orientating pedestrian routes with commercial zones and commuting facilities, this concept of mixed-use development promotes sustainable living and reduction of carbon emissions while providing employment and passenger convenience. Under its action plans, walkable, safe and liveable designs to be developed include Park and Ride installations (LCB 1-5) linking transit nodes with facilities such as luggage lockers, bicycle rental and stands, cashless ticketing system and public services. The blueprint notes that up to $54 \%$ of carbon reduction is achievable for Iskandar City by 2025 if low carbon aspects of transportation, lifestyle and environmental care were fully integrated (LCB 0-5). An attitude of scepticism among landowners and property developers was "to be expected" (LCB 3-8) towards LCB adoption, and soft incentives in the form of green building certification, rather than monetary rewards, are proposed to entice corporate investors who take up the smart urban growth challenge. 


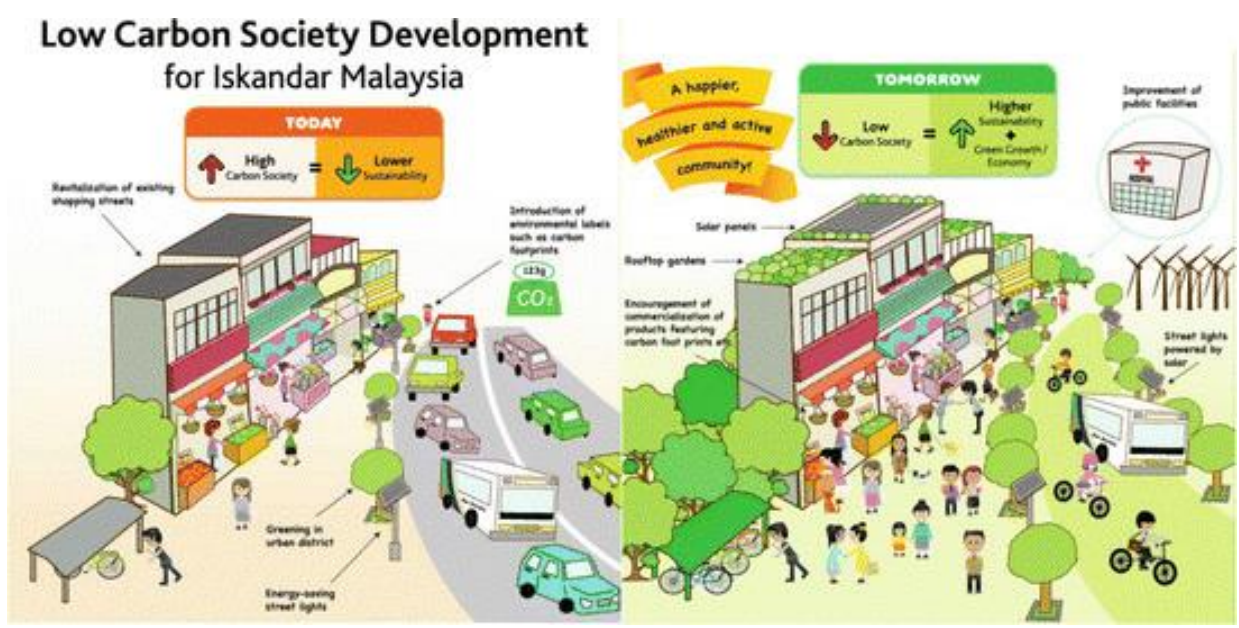

Figure 1: Low Carbon City concept for Iskandar Malaysia

Source: Academic Library, 2014

\section{Case Study II: River of Life (ROL) Project}

Ownership is a valuable benefit sharing outcome of aesthetic landscape design. The River of Life (ROL) initiative began in 2010 when the Kuala Lumpur City Hall empowered the Department of Irrigation and Drainage (DID) to turn Greater Kuala Lumpur, the urban zone populated by four million, served by Klang and Gombak rivers and their waterways, into one of the Most Liveable Global Metropolises by 2020 (River of Life, 2017). As part of the national economic transformation programme (ETP), ROL targets to enhance urban economic, land development and tourism opportunities through the implementation of master planning, cleaning and beautification of the historically important rivers, both which have seen better days since Malaya's tin mining era in 1800s (Figure 2). As the capital grew into an economic outpost for the British and post-colonial independence, it accumulated infamy from decades of pollution due to sewage dumping, and indiscriminate littering, from refrigerators to carcasses (Malaysian Digest, 2017). International master-planning architects are steering the US $\$ 1.3 \mathrm{bil}$ (RM4.4bil) project to elevate commercial value and liveability through $10.7 \mathrm{~km}$ of vibrant landscaped waterfronts, scenic parks, walkways and cycle lanes (AECOM, 2017). 


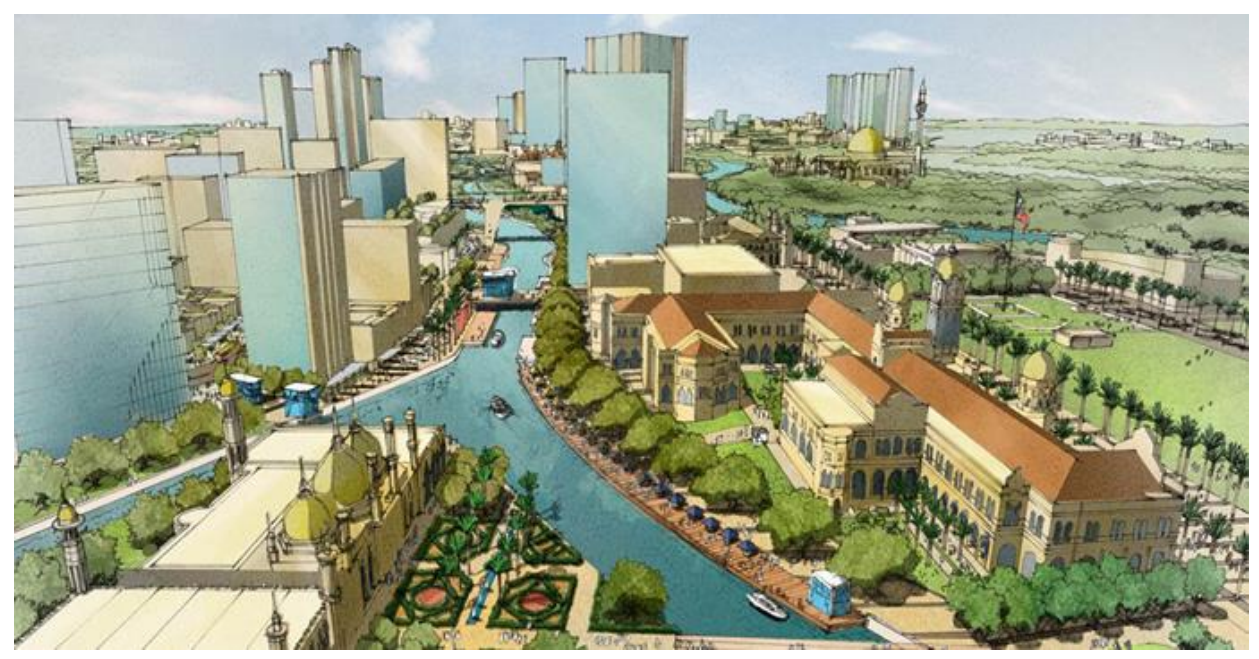

Figure 2: River of Life upon completion Source: Malaysian Digest, 2017

Over the years, the challenge to establish ground support through ownership of river sustainability initiatives was much debated. Non-profit organisations claimed that the federal government, typically locked in its selfserving role, had neglected public perceptions:

"They [the authorities] say that, we are taxpayers ... why should we be helping with the river? Instilling [awareness, knowledge and skills helps the public] reconnect with the river [They] cannot relate with the importance of rivers in daily lives as water consumption can easily be accessed without having to go directly to rivers" (Malaysian Digest, 2017).

To address the issue, a public outreach programme (POP) was launched after initial pilot testing, aimed to create awareness, knowledge and skills towards attitudinal and behavioural changes using preventative, monitoring and auditing approaches, with emphasis on consultation, partnerships and communication of activities and initiatives between DID and over twenty governmental agencies with local stakeholder communities (Chan, 2016). This improved the visibility of ROL project in national media and alternative information channels such as social networks. Further engagement included organising campaigns, competitions, talks, workshops, trainings, as well as encouraging citizen reporting and online discussions (GEC, 2017). 
PLANNING MALAYSIA

Journal of the Malaysia Institute of Planners (2018)

\section{DISCUSSION AND RECOMMENDATIONS}

Malaysian urban design planning cases discussed demonstrate the importance public-private sector collaborations in improving environmental justice outlook for the medium and long term. Qualitative research indicates urban design quality effectively fulfils the basic concept of resilience and adaptiveness but while understanding of sustainability and liveability may have increased, questions of socioeconomic and sociocultural justice to stakeholders, persist. In integrating environmental justice and urban design planning, initiatives to address climate change such as developing renewable energy sources, pollution reduction, waterway preservation and low-carbon policies, remain among the key concerns among authorities and economic sectors (KeTTHA, 2009; Universiti Teknologi Malaysia, 2013). Social sustainability agendas are still relatively undervalued. Despite existing policies fostering ecologically sustainable options, an integrative framework that facilitates growth of liveable cities with socioeconomic and cultural fundamentals, is relatively under-implemented and weak. This can be attributed to several reasons: the lack of support from private sector investors, prohibitive costs of sustainability investments, lack of awareness towards the value of ecological resources and cultural attitudes towards landscapes and heritage preservation. Contestations are compounded with over-urbanisation issues: haphazard solutions for stuttering problems like waste dumping, pothole, burst water pipes or open burning; attitudinal indifference to sustainable development, material culture aspirations, and sense of disconnect with conflated economic change agendas (Gobster et al., 2007). Furthermore, considering the vested nature of stakeholder participation in infrastructural development in Malaysia, Tan (2012) argues that the process of designing, implementation and ensuring efficient access to crucial services such as water has resulted in privatisation measures that, while lucrative for government-linked corporations, have failed to generate capital returns, reflecting rent-seeking behaviours characteristic of biased political interests. Washburn (2013), a former chief urban designer of New York, believes the level of civic involvement determines the quantum and quality of public space transformation: "[Building] a fortress of technology that could withstand tidal waves while emitting no carbon would not be [considered] an urban design success if it embittered its residents."(p.8)

It is hence recommended the authorities provide actionable, enabling mechanisms for environmental justice under sustainable policy frameworks to ensure urban resilience besides increasing emotional interactions with aesthetic landscapes (Gobster et al., 2007; Dovey \& Pafka, 2016). Ensuring guiding policies are in line with internationally prescribed emissions levels in compliance with Environmental Quality Regulations 2009 (DOE, 2010) without hampering aspirations for metropolis growth, are key issues that urban planners should prioritise to measure the degree of sustainability effectiveness (Aiyeola et al., 2014). 
Stephen T.F. Poon

The Viability of an Integrative Framework for Urban Design and Regional Environmental Justice

Resource and energy efficiencies are important in development of healthy spaces balancing sociocultural, physical and psychological aspects (Dadashpour, Azizi, \& Asgharzade, 2016). In city campuses and schools, there are opportunities to design and incorporate green systems such as solar panelling and solar roofs (Chance, 2012). Other practical approaches that inculcates transformation design thinking include incorporating vertical walls within commercial complexes, as well as harnessing unused spaces such as rooftops for small-scale gardening and urban food production, its upside being pesticide-free methods (IDRC, 2006). Sustainability strategies also require the contextual appropriation of past heritage values for the present. One method to preserve sociocultural integrity without heavy redevelopment costs is through integrating spatial models with heritage aesthetics enhancing the perceptual realm of experiences of modern urbanity (Gobster et al., 2007). The conversion of vacant properties into educational or commercial hubs with heritage elements intact is a cost-effective proposition (Nassauer \& Raskin, 2014).

From an environmental law standpoint, Noor Mohammad (2011) suggests that suitable actions be taken to ensure justice amid urban transformation. This includes communication and education for awareness of land rights and resource management, ensuring accessible and ethical information related to environmental impact assessments (EIA) by authorities, state agencies, the media, human rights advocates and international environmental alliances). Aside from regulatory frameworks, training and awareness for officers and taskforces are required to build stronger social capital networks between authorities, community stakeholders and the media. Decisive and rigorous enforcement of existing urban planning laws and anti-pollution policies ensures communities are held responsible for their own urban lifestyle management in aiming for better personal health and social wellbeing.

\section{CONCLUSION}

Case studies from Malaysia have suggested an evolutionary pattern of sustainability actions from randomly-implemented, community-based undertakings to more organised programmes and social advocacy movements, aligning to sustainability frameworks under the National Green Technology Policy and Low Carbon Cities Framework (KeTTHA, 2009). As stakeholder commitment to reduce energy dependency, promote green technology and adopt sustainable infrastructure solutions increase, resource management and transportation improves. Distributive justice is a critical urban planning principle in this scenario (Aiyeola et al., 2014), and ensuring benefit sharing outcomes through higher stakeholder participation is clearly a key determinant for the future of urban-engineered social projects.

Findings have suggested that urban designers must better communicate appreciation of sociocultural benefits of sustainability, instead of framing the 
whole discourse around economic policies. Urban design serves the goals of environmental justice by ensuring early, accurate and transparent dissemination of information from policymakers to stakeholders. Alliances comprising architects, landscape designers, community business owners, NGOs, local urban design researchers and international counterparts must engage in discussions on urbanisation, assessing impacts to environment and society by identifying specific problems and proposing cost-effective opportunities to broaden appreciation of sustainable urban design. Dialogues centring on socio-spatial planning policies improve critical awareness and understanding of urban transformation solutions.

\section{REFERENCES}

AECOM (n.d.). River of Life Kuala Lumpur. Retrieved from http://www.aecom.com/my/projects/river-life/

Aiyeola, A., Ramdzani, A., Nasir, S., \& Zalina, Z. I. (2014). Public participation in environmental impact assessment process: MRT project in Malaysia. Journal of Environmental Science, Toxicology and Food Technology, 8(6), 8-12.

Bettencourt, L. M. A., Lobo, J., Helbing, D., Kühnert, C., \& West, G. B. (2007). Growth, innovation, scaling, and the pace of life in cities. Proceedings of the National Academy of Sciences, 104(17), 7301-6.

Bullard, R. D. (2008). Environmental justice in the $21^{\text {st }}$-Century. Environmental Justice Resource Centre. $\quad$ Retrieved from http://www.deanza.edu/faculty/sullivanmark/pdf/bullard.pdf

Cities Climate Leadership Group [C40] (2016). 100 solutions for climate action in cities Copenhagen: Sustainia.

Carmona, M. (2013). The place-shaping continuum: A theory of urban design process. Journal of Urban Design, 19(1), 2-36.

Carmona, M., \& Tiesdell, S. (Eds.) (2007). Urban design reader. Burlington, MA: Architectural Press/Elsevier.

Chan, J. (2016, October 13) 'Local community engagement key to success of foundation's water project'. The Star Available at: http://www.thestar.com.my/metro/community/2016/10/13/having-a-heart-forrivers-local-community-engagement-key-to-success-of-foundations-waterproject/

Chance, S. (2012). Planning for environmental sustainability: Learning from LEED and the USCBC. Planning for Higher Education, 41(1), 194-232.

Cullen, G. (1961). TownScape. London: Architectural Press.

Dadashpour, H., Azizi, D., \& Asgharzade, P. (2016). Evaluating the liveable capacity of urban neighborhoods in Tehran: A case study of Harandi, Takhti and Kosar neighborhoods. Journal of Geography and Urban Space Development, 3(2), 1518.

Department of Environment Malaysia [DOE] (2010). Environmental requirements: A guide for investors. Retrieved from http://www.doe.gov.my/eia/wpcontent/uploads/2012/03/A-Guide-For-Investors1.pdf 
Stephen T.F. Poon

The Viability of an Integrative Framework for Urban Design and Regional Environmental Justice

Dovey, K., \& Pafka, E. (2016). The science of urban design? Urban Design International, 21(1), 1-10.

Global Environment Centre [GEC]. (n.d.). Retrieved from http://www.gec.org.my/

Gobster, P. H., Nassauer, J. I., Daniel, T. C., \& Fry, G. (2007). The shared landscape: What does aesthetics have to do with ecology? Landscape Ecology, 22, 959-972.

Hens, L., \& Stoyanov, S. (2014). Education for climate changes, environmental health and environmental justice. Journal of Chemical Technology and Metallurgy, 49(2), 194-208.

International Development Research Centre [IDRC] (2006). Cities farming for the future: Urban agriculture for green and productive cities. Ottawa, Canada: IDRC.

Jacobs, M. (1999). Sustainable development as a contested concept. In A. Dobson (Ed.) Fairness and futurity: Essays on environmental sustainability and social justice. Oxford: OUP

Lang, J. (2005). Urban design: A typology of procedures \& products. Oxford: Architectural Press.

Malaysian Digest (2017, January 3). Revitalising the Klang and Gombak rivers will cost the govt RM4.3bil, what are the benefits? Malaysian Digest. Retrieve from http://malaysiandigest.com/frontpage/282-main-tile/650846-revitalising-theklang-and-gombak-rivers-will-cost-the-govt-rm4-3-bil-what-are-thebenefits.html

Martin, A., McGuire, S., \& Sullivan, S. (2013). Global environmental in/justice and biodiversity conservation. Geographical Journal, 179(2), 122-31.

McCluskey, D., \& Joao, E. (2011). Promotion of environmental enhancement in Strategic Environmental Assessment. Environmental Impact Assessment Review, 31, 34451.

Ministry of Energy, Green Technology and Water Malaysia [KeTTHA] (2009). National Green Technology Policy. Putrajaya, Malaysia.

Nassauer, J., \& Raskin, J. (2014). Urban vacancy and land use legacies: A frontier for urban ecological research, design, and planning. Landscape \& Urban Planning, $125,245-253$

Nassauer, J. I., Wu, J. G., \& Xiang, N. (2014). Actionable urban ecology in China: Integrating ecology and planning for sustainable cities. Landscape \& Urban Planning, 125, 207-8.

Noor Mohammad (2011). Need to implement the environmental communication mechanisms for sustainable development. African Journal of Business Management, 5(35), 13352-8.

Pieterse, J. N. (Ed.) (2001). Global futures: Shaping globalisation. London: Zed Books.

Rice, L., \& Littlefield, D. (Eds.) (2015). Transgression: Towards an expanded field of architecture. Abingdon: Routledge.

River of Life (2016). Retrieved from http://riveroflife.com.my

Rugg, R. (2014, August 11). Low carbon cities are the core of Malaysia's green future. Carbon Trust. Retrieved from www.carbontrust.com/news/2014/08/lowcarbon-cities-malaysia-green-future/

Stake, R. E. (1995). The art of case study research. Thousand Oaks: Sage.

Tan, J. (2012). The pitfalls of water privatisation: Failure and reform in Malaysia. World Development, 40(12), 2552-63. 
PLANNING MALAYSIA

Journal of the Malaysia Institute of Planners (2018)

United States Environmental Protection Agency [US EPA] (2017). Environmental justice. Retrieved from https://www.epa.gov/environmentaljustice

Universiti Teknologi Malaysia (2013). Low carbon society blueprint for Iskandar Malaysia 2025. Johor Bahru, Malaysia: UTM-Low Carbon Asia Research Center.

Washburn, A. (2013). The nature of urban design: A New York perspective on resilience. Washington DC: Island Press.

Walker, B., \& Salt, D. (2006). Resilience thinking: Sustaining ecosystems and people in a changing world. Washington DC: Island Press.

Wolch, J. R., Byrne, J., \& Newell, J. (2014). Urban green space, public health \& environmental justice: The challenge of making cities 'just green enough'. Landscape \& Urban Planning, 125, 234-244.

World Bank (2014). Climate-resilient, climate-friendly world heritage cities. June: No 19. Retrieved from https://openknowledge.worldbank.org/urban

Yin, R. K. (2003). Case study research: Design and methods ( $3^{\text {rd }}$ ed). Thousand Oaks, CA: Sage.

\section{Images Credit}

Figure 1: Iskandar Regional Development Authority [IRDA] (2014). Retrieved from http://www.irda.com.my/

Figure 2: Malaysian Digest (2017, January 3). Revitalising the Klang and Gombak rivers will cost the govt RM4.3bil, what are the benefits? Malaysian Digest. Retrieve from http://malaysiandigest.com/frontpage/282-main-tile/650846-revitalisingthe-klang-and-gombak-rivers-will-cost-the-govt-rm4-3-bil-what-are-thebenefits.html 